\title{
CALCIUM ENTRY CAUSES A PROLONGED REFRACTORY PERIOD IN PEPTIDERGIC NEURONS OF APLYSIA
}

\author{
L. K. KACZMAREK ${ }^{2}$ AND J. A. KAUER \\ Departments of Pharmacology and Physiology, Yale University School of Medicine, New Haven, Connecticut 06510
}

Received February 1, 1983; Revised April 21, 1983; Accepted May 5, 1983

\begin{abstract}
A brief train of electrical stimuli to the pleuroabdominal connective of Aplysia produces a cumulative depolarization in the peptidergic hag cell neurons within the abdominal ganglion. This response is followed by an afterdischarge which lasts for about $30 \mathrm{~min}$, and then by a prolonged refractory period lasting for several hours. During the refractory period the cumulative depolarization in response to stimulation is attenuated, and stimulation either fails to initiate afterdischarges or produces discharges of much shorter duration.

We have used the cationophore X537A to lest the hypothesis that the prolonged refractory period is caused by calcium entry into the bag cell neurons during the afterdischarge. Exposure of intact bag cell clusters to X537A at concentrations from 1 to $10 \mu \mathrm{M}$ for a period of $20 \mathrm{~min}$ in calciumcontaining media produced no change in their resting potentials or in their ability to generate action potentials, but induced a state resembling natural refractoriness in response to subsequent stimulation. Both natural refractoriness and that induced by X537A could be overcome by extracellular tetraethylammonium ions $(90 \mathrm{mM})$. Dose response data showed that concentrations of ionophore of 2.5 to $5.0 \mu \mathrm{M}$ produce an attenuation of afterdischarge that is similar to that following a stimulated afterdischarge. These concentrations of X537A also produced an enhancement of ${ }^{3} \mathrm{H}$-labeled peptide release from these cells that is comparable to that observed on stimulation of an afterdischarge. Moreover, the time course of recovery from exposure to $5.0 \mu \mathrm{M}$ X537A parallels that of natural refractoriness, recovery being essentially complete about $20 \mathrm{hr}$ after X537A exposure or stimulation. The ionophore did not affect the mean duration of afterdischarge when applied in calcium-deficient media.

The electrical effects of X537A were investigated using isolated bag cell neurons in cell culture. After treatment with the adenylate cyclase activator, forskolin, and theophylline, such isolated cells show many of the electrical changes occurring in intact bag cell clusters at the onset of afterdischarge, including the enhancement of action potentials, as well as increased input resistance and the emergence of oscillations in membrane potential. None of these parameters was significantly affected by concentrations of ionophore that induce refractoriness. In response to repetitive intracellular stimulation, however, some forskolin-treated cells undergo a cumulative depolarization which is similar to that seen at the onset of afterdischarge in intact clusters. This cumulative depolarization was found to be attenuated or abolished by $5.0 \mu \mathrm{M}$ X537A. Our data suggest that calcium entry during a bag cell afterdischarge does trigger the subsequent prolonged refractory period and that it does so by attenuating the ability of these cells to depolarize in response to repetitive stimulation.
\end{abstract}

A rise in intracellular calcium concentrations during neuronal activity, in addition to its effects on neurotransmitter secretion, may bring about a variety of transient changes in the electrical properties of neurons through

\footnotetext{
${ }^{1}$ This work was supported by BRSG Grant RR05358 awarded by the Biomedical Research Support Grant Program, Division of Research Resources, National Institutes of Health, and by National Science Foundation Grant BNS-8202364 to L. K. K. We wish to thank Susan A. DeRiemer for her helpful comments.
}

the activation or inactivation of membrane conductances (Mcech, 1978; Tillotson and Horn, 1978; Eckert and Ewald, 1982). In general, these effects operate on a time scale of milliseconds to minutes. In this paper we report that a transient, ionophore-induced elevation of internal calcium ions in the bag cell neurons of Aplysia induces a

\footnotetext{
${ }^{2}$ To whom correspondence should be addressed, at Department of Pharmacology, Yale University School of Medicine, 333 Cedar Street, New Haven, CT 06510.
} 
state of electrical refractoriness that endures for up to $20 \mathrm{hr}$. This state of refractoriness appears identical, in all respects that we have examined, to the refractory period that naturally follows a 30 -min afterdischarge in these neurons.

The bag cell neurons comprise two clusters of electrically coupled, peptidergic neurons within the abdominal ganglion of Aplysia. Normally, these cells maintain high resting potentials and show no sign of spontaneous activity. Following a brief stimulus train $(5$ to $10 \mathrm{sec})$ to a bag cell cluster or to an afferent pathway from the cerebral ganglion, however, the cells depolarize by 15 to $20 \mathrm{mV}$ and start to discharge repetitively (Kupfermann and Kandel, 1970). This afterdischarge continues for a mean duration of $30 \mathrm{~min}$. The action potentials of the bag cell neurons have a major calcium component (Kaczmarek et al., 1980, 1982; Acosta-Urquidi and Dudek, 1981), and the occurrence of an afterdischarge results in the secretion of neuroactive peptides from these cells, including that of their major secretory product, egglaying hormone (Arch, 1972; Stuart et al., 1980). At the end of the afterdischarge the cells enter the refractory period during which further electrical stimulation of the afferent pathway, or of the bag cell neurons themselves, either fails to produce a second afterdischarge or produces a much shorter discharge with a lower frequency of firing. In addition, the action potentials of these neurons, which normally arise in the distal tips of their neurites and propagate toward the somata, may fail to invade the somata during the refractory period (Dudek and Blankenship, 1977a, b; Kaczmarek et al., 1978). Recovery from refractoriness takes place gradually, over a period of several hours, such that normal full-length afterdischarges can again be obtained 18 to $24 \mathrm{hr}$ after the onset of refractoriness. Afterdischarge in the bag cell neurons triggers egg-laying behavior in Aplysia (Pinsker and Dudek, 1977; Dudek et al., 1979), and it is believed that the refractory period serves as a physiological control to limit the frequency of this behavior.

Previous work on the mechanisms that control changes in the electrical properties of the bag cell neurons has focused on the stimulus-induced afterdischarge. The onset of afterdischarge is associated with an increase in intracellular cAMP levels (Kaczmarek et al., 1978), and many of the electrophysiological changes that occur at the onset of an afterdischarge, including both the onset of membrane potential oscillations that may drive a repetitive discharge and a profound enhancement of calcium action potentials, may be observed in isolated bag cell neurons in cell culture on exposure to cAMP analogues (Kaczmarek and Strumwasser, 1981a, b) or on intracellular injection of the catalytic subunit of cAMPdependent protein kinase (Kaczmarek et al., 1980). On the other hand, little is, as yet, known about the mechanism of the onset of refractoriness. It has been observed, however, that a refractory period following an afterdischarge is only observed in extracellular media containing calcium ions, leading to the hypothesis that calcium entry during the afterdischarge itself triggers cellular events that bring on the refractory period (Kaczmarek et al., 1982). We have now tested this hypothesis using the divalent cationophore X537A (Pressman, 1972), which allows calcium entry without eliciting an afterdischarge.

\section{Materials and Methods}

Mature Aplysia californica (150 to $300 \mathrm{gm}$ ) were obtained from Alacrity Marine Biological Services (Redondo Beach, CA) and were maintained in artificial seawater at $14^{\circ} \mathrm{C}$. The pleuroabdominal connectives that join the abdominal ganglion to the head ganglia were cut close to the pleural ganglia, and the abdominal ganglia were then dissected out with the entire length of these connectives and placed in an artificial seawater medium (ASW) of composition $460.0 \mathrm{~mm} \mathrm{NaCl}, 10.4 \mathrm{mM} \mathrm{KCl}$, $55.0 \mathrm{mM} \mathrm{MgCl} 2,11.0 \mathrm{mM} \mathrm{CaCl}_{2}, 10 \mathrm{mM}$ Tris- $\mathrm{HCl}, \mathrm{pH}$ 7.8 .

For extracellular recordings from the bag cell neurons the ganglia were placed in a recording chamber at $14^{\circ} \mathrm{C}$, and a suction electrode for stimulation was placed at the distal end of one connective. A recording suction electrode was placed at the rostral end of the corresponding bag cell cluster. This positioning of the recording electrode allows one to record large compound action potentials, which represent the synchronous firing of all 200 to 400 cells within the cluster, and also allows one to detect failure of transmission from the neurites of these cells which extend along the proximal 5.0 to $10.0 \mathrm{~mm}$ of the connective nerve.

For intracellular experiments, in intact bag cell clusters, the connective tissue overlying the bag cell clusters was first softened by preincubation of the ganglia for 2 $\mathrm{hr}$ in ASW containing $2 \mathrm{mg} / \mathrm{ml}$ of collagenase and 0.5 $\mathrm{mg} / \mathrm{ml}$ of Elastase (Boehringer Mannheim Biochemicals, Indianapolis, IN) at $20^{\circ} \mathrm{C}$. After rinsing in ASW the ganglia were placed in the recording chamber at $14^{\circ} \mathrm{C}$ and attached to extracellular suction electrodes as described above. Glass microelectrodes were filled with $3 \mathrm{M}$ $\mathrm{KCl}$ and typically had resistances of 15 to 30 megohms. Recordings were made through an S-7071 electrometer (W-P Instruments, Inc., New Haven, CT). Intracellular stimulation was achieved by passing current through the recording electrode, after correcting for bridge imbalance. Action potentials and afterdischarge recordings were stored on oscilloscope disc (Nicolet Instrument Corp., Madison, WI) and polygraph chart records.

To stimulate afterdischarges a suction electrode was placed at the distal end of a pleuroabdominal connective, and stimulus trains of increasing intensity were given until an afterdischarge was triggered in the bag cell neurons. The parameters of the stimulus trains used in these experiments are given in Table $\mathrm{I}$, in order of increasing intensity. In a previously unstimulated ganglion, parameter sets 1 or 2 were usually sufficient to evoke afterdischarge. In the refractory period, or after exposure to ionophore, the stimulus trains were given

TABLE I

Stimulus parameters for the initiation of afterdischarges

\begin{tabular}{ccccc}
$\begin{array}{c}\text { Trial } \\
\text { No. }\end{array}$ & $\begin{array}{c}\text { Duration of } \\
\text { Stimulus Train } \\
\text { (sec) }\end{array}$ & $\begin{array}{c}\text { Stimulus voltage } \\
\text { (V) }\end{array}$ & $\begin{array}{c}\text { Frequency } \\
\text { of } \\
\text { Pulses } \\
\text { (Hz) }\end{array}$ & $\begin{array}{c}\text { Pulse width } \\
\text { (msec) }\end{array}$ \\
\hline 1 & $<10$ & $10-20$ & $<2$ & 2.5 \\
2 & 5 & 20 & 6 & 2.5 \\
3 & 10 & 20 & 6 & 2.5 \\
4 & 15 & 20 & 6 & 2.5 \\
5 & 15 & $40-60$ & 6 & 2.5 \\
\hline
\end{tabular}


one after another in the order shown in the table, usually with an interval of $1 \mathrm{~min}$ or more between trials, until an afterdischarge resulted. If failure of action potential propagation occurred during these stimulus trains, the stimulating electrode was moved closer to the bag cell neurons or onto the bag cell cluster itself and the stimulation was repeated. If no afterdischarge occurred with maximal stimulation, the duration of afterdischarge was scored as zero.

Isolated bag cell neurons in cell culture were prepared by incubating abdominal ganglia at $22^{\circ} \mathrm{C}$ for $6 \mathrm{hr}$ in filtered seawater containing $1.25 \%$ neutral protease with neomycin sulfate $(100 \mu \mathrm{g} / \mathrm{ml})$ (Kaczmarek et al., 1979). After removal of the connective tissue capsules, the bag cells were disaggregated using a Pasteur pipette and seeded into 35-mm Falcon tissue culture dishes containing Eagle's minimal essential medium in ASW containing $15 \mathrm{mM}$ HEPES (4-(2-hydroxyethyl)-1-piperazineethanesulfonic acid, $\mathrm{pH} \mathrm{7.8)}$ and neomycin sulfate (50 $\mu \mathrm{g} / \mathrm{ml})$. The cells rapidly attached to the bottom of the culture dishes and were maintained at $14^{\circ} \mathrm{C}$. Intracellular recordings from cultured bag cell neurons were carried out at room temperature using cells that had been in culture for no longer than 2 weeks.

The ionophore X537A was obtained as the sodium salt (Ro 2-2985/1) from Dr. W E. Scott of Hoffman-La Roche, Inc. (Nutley, NJ), and kept as a $2 \mathrm{mM}$ or $10 \mathrm{mM}$ stock solution in ethanol. The adenylate cyclase activator, forskolin, was obtained from Calbiochem-Behring Corp. (San Diego, CA). To achieve the final concentrations of pharmacological agents used in this study, $5 \mu \mathrm{l}$ or more of a more concentrated solution were added directly to the extracellular medium.

For experiments in which the release of ${ }^{3} \mathrm{H}$-labeled peptides was investigated, abdominal ganglia were further dissected to give left and right hemiganglia, each containing one bag cell cluster with its associated pleuroabdominal connective nerve. Hemiganglia were incubated in $0.5 \mathrm{ml}$ of ASW containing $25 \mu \mathrm{Ci}$ of $\mathrm{L}-\left[4,5-{ }^{3} \mathrm{H}\right]$ leucine $(60 \mathrm{Ci} / \mathrm{mmol})$ for $20 \mathrm{hr}$ at $14^{\circ} \mathrm{C}$, after which they were rinsed with four to five changes of radioactivityfree ASW over a period of 2 to $3 \mathrm{hr}$. The extracellular medium $(200 \mu \mathrm{l})$ was subsequently changed at 10 -min intervals, samples of the superfusate being taken for analysis of released ${ }^{3} \mathrm{H}$-peptides. After $50 \mathrm{~min}$ of superfusion, ionophore was added to the superfusion medium or the bag cells were stimulated to afterdischarge through a suction electrode at the distal end of the pleuroabdominal connective. Superfusion was then continued as before for an additional $60 \mathrm{~min}$ or more. Radiolabeled peptides within the samples of superfusate were precipitated by the addition of an equal volume of trichloracetic acid (5\%) after the addition of bovine serum albumin ( 5 $\mu \mathrm{g} / \mathrm{ml}$ ) as carrier. The precipitate was collected by centrifugation $(1600 \times g, 10 \mathrm{~min})$, rinsed, and recentrifuged three times in 5\% trichloroacetic acid, dissolved in $1.0 \mathrm{~N}$ $\mathrm{NaOH}$, and then neutralized with $\mathrm{HCl}$ prior to counting by liquid scintillation. In seven experiments the released labeled superfusate, or the resolubilized pellet, was layered directly onto a BioGel P-10 column $(10 \times 1 \mathrm{~cm})$. Analysis of the eluate from this column indicated that the major portion of released peptide cpm under these conditions were of $M_{\mathrm{r}}>15,000$, as has been observed by others (Stuart et al., 1980).

\section{Results}

The onset of the refractory period. In a previously unstimulated abdominal ganglion, stimuli to the distal end of a pleuroabdominal connective may trigger a longlasting afterdischarge in the bag cell neurons. The electrophysiological changes that occur with stimulation have been described in detail elsewhere (Kupfermann and Kandel, 1970; Dudek and Blankenship, 1977a; Kaczmarek et al., 1982). Figure 1 shows an intracellular recording from a single bag cell neuron within a cluster at the onset of an afterdischarge. Stimulation $(20 \mathrm{~V}, 2.5$ msec) at a low frequency $(<2 \mathrm{~Hz})$ for a few seconds is usually sufficient to trigger the afterdischarge, although more prolonged stimulation (up to $20 \mathrm{~V}, 2.5 \mathrm{msec}, 6 \mathrm{~Hz}$, $15 \mathrm{sec}$ ) is occasionally required. Once triggered, however, the afterdischarge proceeds in a fixed manner and with a duration that is independent of the stimulus parameters. As seen in Figure 1, stimulation (in this case 5
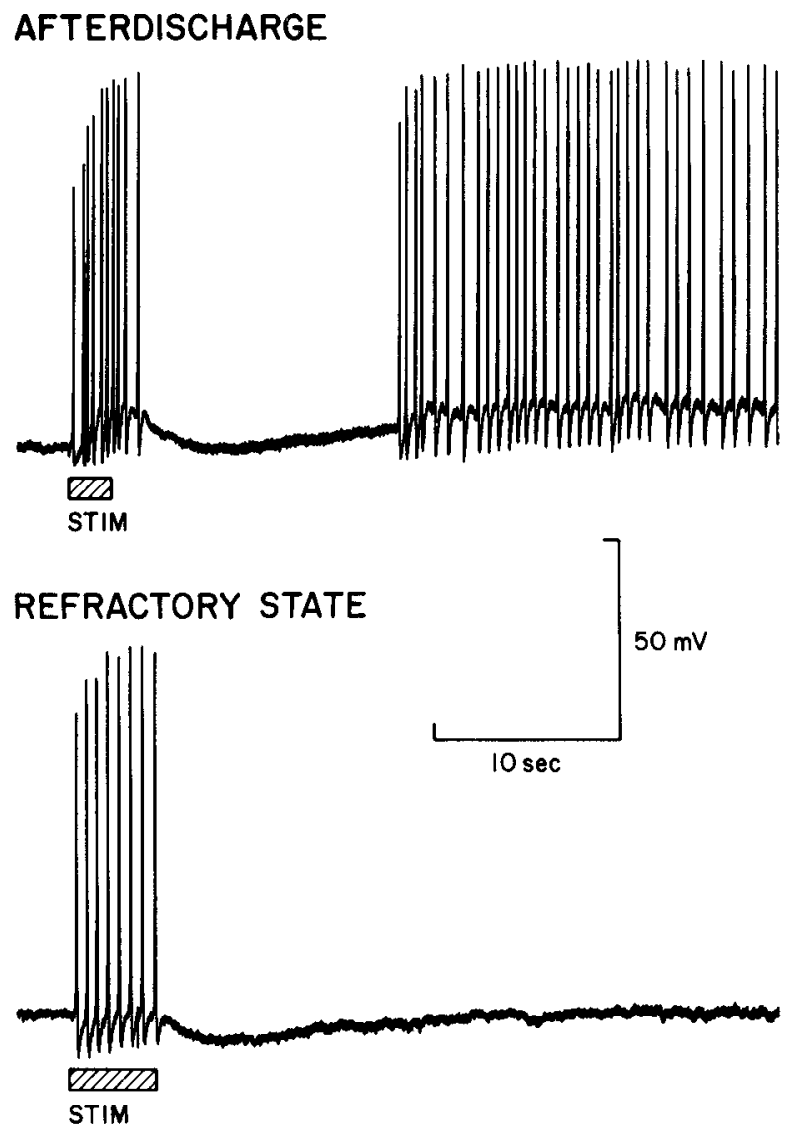

Figure 1. Intracellular recordings from a bag cell neuron at the onset of an afterdischarge triggered by brief stimulation of the pleuroabdominal connective nerve $(2.5 \mathrm{msec}, 20 \mathrm{~V}$ pulses, $1.67 \mathrm{~Hz}, 5$ pulses $)$ and during the refractory period $(2.5 \mathrm{msec}$, $20 \mathrm{~V}, 1.67 \mathrm{~Hz}, 8$ pulses, given $12 \mathrm{~min}$ after the end of the afterdischarge). At the onset of afterdischarge, a cumulative depolarization is observed during stimulation. In the refractory state no cumulative depolarization is seen during stimulation, which fails to produce an afterdischarge. 
pulses at $1.67 \mathrm{~Hz}, 20 \mathrm{~V}, 2.5 \mathrm{msec}$ ) triggers action potentials superimposed on a cumulative depolarization of the membrane potential. Because of this cumulative depolarization, pulses after the first stimulus pulse may trigger multiple action potentials. On termination of stimulation the membrane potential hyperpolarizes transiently and then again depolarizes to generate the discharge after a delay of up to $15 \mathrm{sec}$.

At the end of an afterdischarge, stimulation comparable to that which triggered the first afterdischarge generally fails to trigger a second afterdischarge. The lower trace in Figure 1 shows that a longer stimulus train (8 pulses) of the same intensity and frequency as were used to trigger the afterdischarge now fails to produce a cumulative depolarization during stimulation itself or to generate an afterdischarge.

More intense stimulation (Table I) may sometimes trigger an afterdischarge after the onset of the refractory period. Such subsequent afterdischarges are, however, of significantly lower firing frequency and duration than the first afterdischarge (Kaczmarek et al., 1978, 1982). The mean durations of the first afterdischarge (1st AD) and that of a subsequent afterdischarge $(2 n d A D)$, induced by stimulation within $1 \mathrm{hr}$ after the termination of the first afterdischarge, are shown in Figure $3 \mathrm{~A}$ for five abdominal ganglia. During the refractory period, action potentials which originate in the distal tips of bag cell neurites, 5 to $10 \mathrm{~mm}$ from the somata, also frequently fail to invade the somata but may still be observed in extracellular recordings from suction electrodes over the proximal connective nerve (Dudek and Blankenship, 1977a; Kaczmarek et al., 1978).

X537A diminishes afterdischarge duration. Intracellular recordings from bag cell neurons in the abdominal ganglion showed that exposure to the divalent cationophore X537A at concentrations of 1 to $10 \mu \mathrm{M}$ did not induce any significant change in the resting potential of these neurons. The exposure of unstimulated abdominal ganglia to X537A, in concentrations greater than $1.0 \mu \mathrm{M}$ for a period of $20 \mathrm{~min}$, however, resulted in a diminution of the duration of afterdischarges (Fig. $2 A$ ) or in a failure to afterdischarge (Fig. $2 C$ ), in response to subsequent stimulation. Figure $2 A$ shows intracellular and extracellular recordings of a bag cell afterdischarge induced by repetitive stimulation $(20 \mathrm{~V}, 2.5 \mathrm{msec}, 6 \mathrm{~Hz}, 15 \mathrm{sec})$, following exposure to $5 \mu \mathrm{M}$ ionophore for $20 \mathrm{~min}$. The duration of this discharge is only $2 \frac{1}{2} \mathrm{~min}$, compared with the expected duration of about 30 min for an untreated bag cell cluster. The dose-response relation for the attenuation of afterdischarge duration by ionophore concentrations from 1.0 to $300.0 \mu \mathrm{M}$ is shown in Figure $3 B$. Ionophore concentrations between 2.5 and $10 \mu \mathrm{M}$ produced a diminution of mean afterdischarge duration comparable to that induced by a prior afterdischarge (Fig. $3 \mathrm{~A}$ ). A standard exposure of $5 \mu \mathrm{M}$ X537A for $20 \mathrm{~min}$ was therefore used in most of the subsequent experiments to be described.

In many respects this refractory state that is induced by $\mathrm{X} 537 \mathrm{~A}$ is similar to that which normally follows a long-lasting afterdischarge. The intracellularly recorded
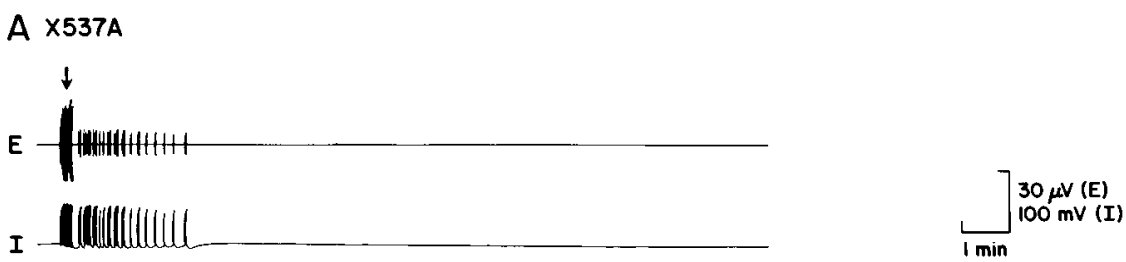

B NORMAL ASW
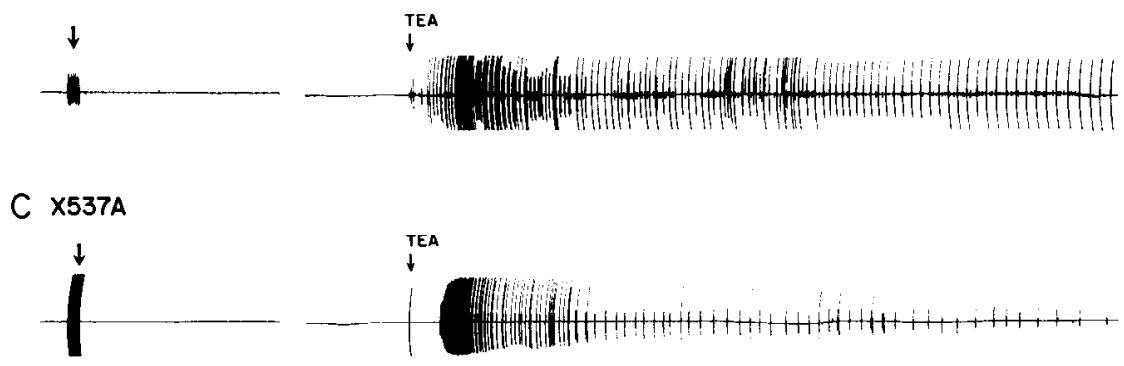

Figure 2. A, Simultaneous intracellular $(I)$ and extracellular $(E)$ recordings from a bag cell cluster at the onset of a short afterdischarge triggered by stimulation $(20 \mathrm{~V}, 2.5 \mathrm{msec}, 6 \mathrm{~Hz}, 15 \mathrm{sec})$ after exposure of the abdominal ganglion to $5 \mu \mathrm{M}$ X $537 \mathrm{~A}$ for $20 \mathrm{~min}$. The extracellular recordings represent the synchronous firing of 200 to 400 neurons within the cluster. $B$, Extracellular recording showing that failure to afterdischarge during the refractory period may be overcome by extracellular TEA ions. The first arrow indicates a period of stimulation $(20 \mathrm{~V}, 2.5 \mathrm{msec}, 6 \mathrm{~Hz}, 15 \mathrm{sec})$ after the end of an afterdischarge in normal ASW. The second arrow indicates the extracellular addition of $90 \mathrm{mM}$ TEA, within $10 \mathrm{~min}$ of the stimulation. TEA causes the bag cell neurons to start discharging in synchrony. $C$, Inability to afterdischarge after exposure to X537A may also be overcome by extracellular TEA. The first arrow shows a period of stimulation $(20 \mathrm{~V}, 2.5 \mathrm{msec}, 6 \mathrm{~Hz}, 15 \mathrm{sec})$ to the connective nerve after exposure of the abdominal ganglion to $5 \mu \mathrm{M}$ X537A. The extracellular recording shows that stimulation failed to trigger an afterdischarge. About $10 \mathrm{~min}$ after stimulation, $90 \mathrm{mM}$ TEA was bath applied (second arrow) and initiated a characteristic bag cell discharge. 

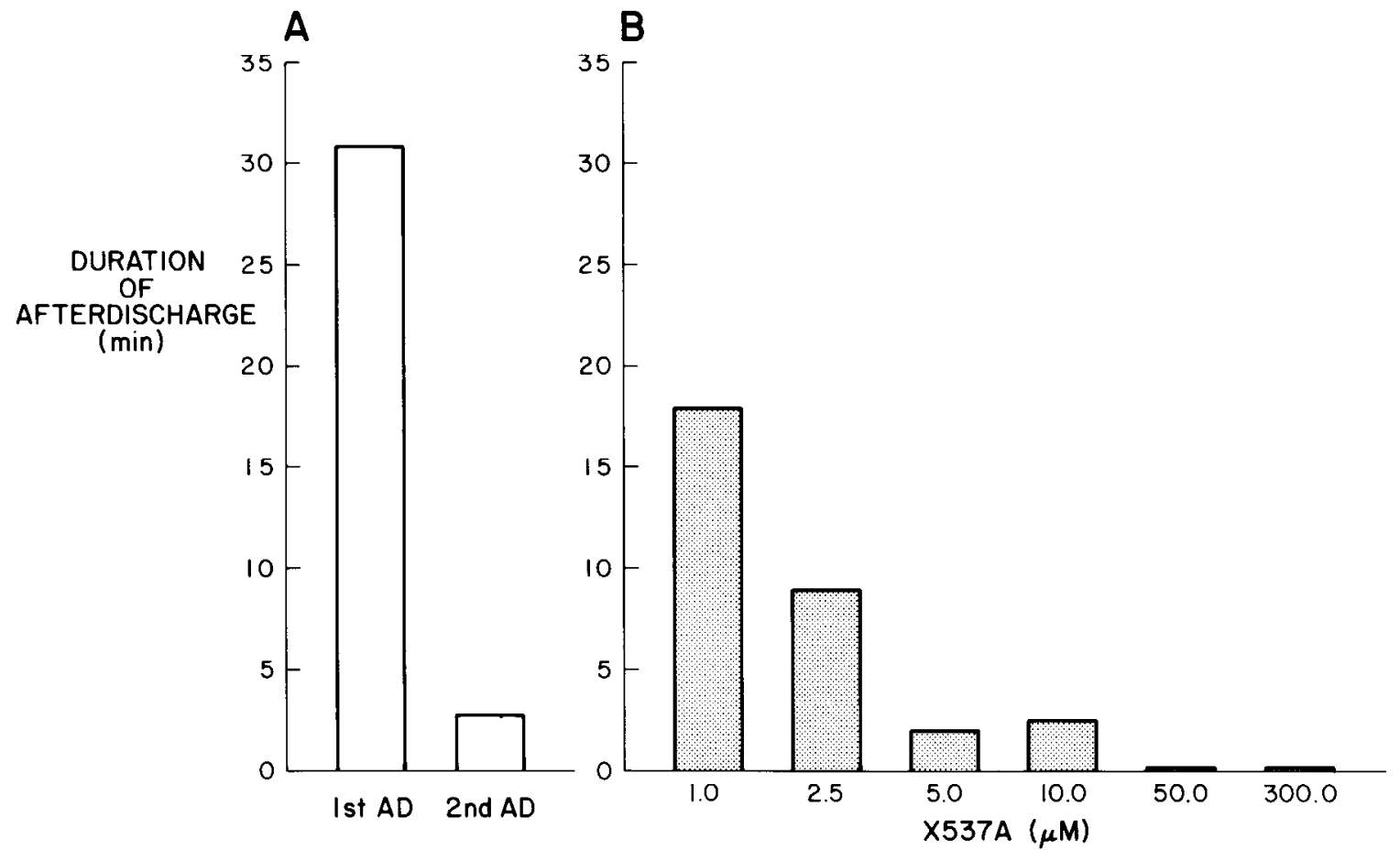

Figure 3. $A$, The mean duration of a first afterdischarge (1st $A D$ ) in a normal medium and the mean duration of discharges induced by subsequent stimulation $(2 n d A D)$ within $1 \mathrm{hr}$ of the end of the first afterdischarge $(n=5)$. B, The effect of a 20 -min exposure to different concentrations of X537A on the duration of a first afterdischarge. The number of determinations for ionophore concentrations of $1.0,2.5,5.0,10.0,50.0$, and $300.0 \mu \mathrm{M}$ are 2, 2, 5, 2, 4, and 1, respectively. Exposure to an ionophore concentration of 2.5 to $5.0 \mu \mathrm{M}$ produces a diminution in duration of afterdischarge comparable to that produced by a prior after discharge.

spikes remain in phase with the extracellular traces, which represent the synchronous firing of most or all of the bag cell neurons in a cluster, indicating that the cells remain adequately coupled after exposure to $5 \mu \mathrm{M}$ ionophore (Fig. 2A). As is the case for refractoriness induced by a.prior afterdischarge, failure to afterdischarge was associated with the loss of the cumulative depolarization during stimulation. Both the cumulative depolarization during stimulation and the subsequent long-lasting depolarization could still be detected in those cases where stimulation did trigger an afterdischarge but were, apparently, of insufficient magnitude to trigger more than a short discharge. Moreover, intense stimulation (Table 1 , trials 4 and 5) was usually required to generate these short discharges.

The action potentials of the bag cell neurons, in response to stimulation of the connective nerve, appeared normal following exposure to $5 \mu \mathrm{M}$ X537A. In some cases, however, action potentials failed to invade fully the bag cell somata, as is also observed with refractoriness induced by a prior afterdischarge. In two experiments intracellular injection of current was used to evoke bag cell action potentials before and after $5 \mu \mathrm{M}$ X537A exposure. No changes in the height or width of intracellularly recorded spikes were observed. Further analysis of the electrical effects of the ionophore was carried out using isolated bag cell neurons in cell culture and will be described later.

The inability to afterdischarge induced by a prior afterdischarge, in normal ASW, may be overcome by extracellular tetraethylammonium ions (TEA) (Fig. 2B)
(Kaczmarek et al., 1980). This was also the case for the refractory state induced by X537A (Fig. 2C). In those cases where stimulation had proved ineffective in eliciting an afterdischarge after $20 \mathrm{~min}$ exposure to ionophore concentrations up to $50.0 \mu \mathrm{M}$, the extracellular application of $90 \mathrm{mM}$ TEA-Br resulted in repetitive discharge. Following exposure to $300 \mu \mathrm{M}$ X537A, however, no electrical activily could be recorded from the bag cell neurons in either the presence or absence of TEA.

Time course and calcium dependence of the refractory state induced by $X 537 A$. The normal refractory period that follows a bag cell afterdischarge endures for many hours. The time course of recovery from the refractory state induced by the ionophore was tested in 10 ganglia following exposure to $5 \mu \mathrm{M}$ X537A for $20 \mathrm{~min}$. Figure 4 shows the duration of afterdischarges obtained by stimulation at varying times following exposure to the ionophore. Recovery appeared to be essentially complete after $18 \mathrm{hr}$, the mean duration of discharges after $18 \mathrm{hr}$ being $27.3 \mathrm{~min}$. Also shown is the mean duration of afterdischarges in successive 5 -hr periods following stimulation of an afterdischarge in normal ASW (L. K. Kaczmarek and F. Strumwasser, unpublished data). As can be seen in the figure, the duration and time course of refractoriness induced by the ionophore are similar to those of the normal refractory period.

To determine whether the prolonged effect of X537A on bag cell excitability was dependent on external calcium ions, similar experiments were carried out using a calcium-free medium. Four ganglia were exposed to $5 \mu \mathrm{M}$ $\mathrm{X} 537 \mathrm{~A}$ for 20 min in calcium-free ASW (460 mM NaCl, 


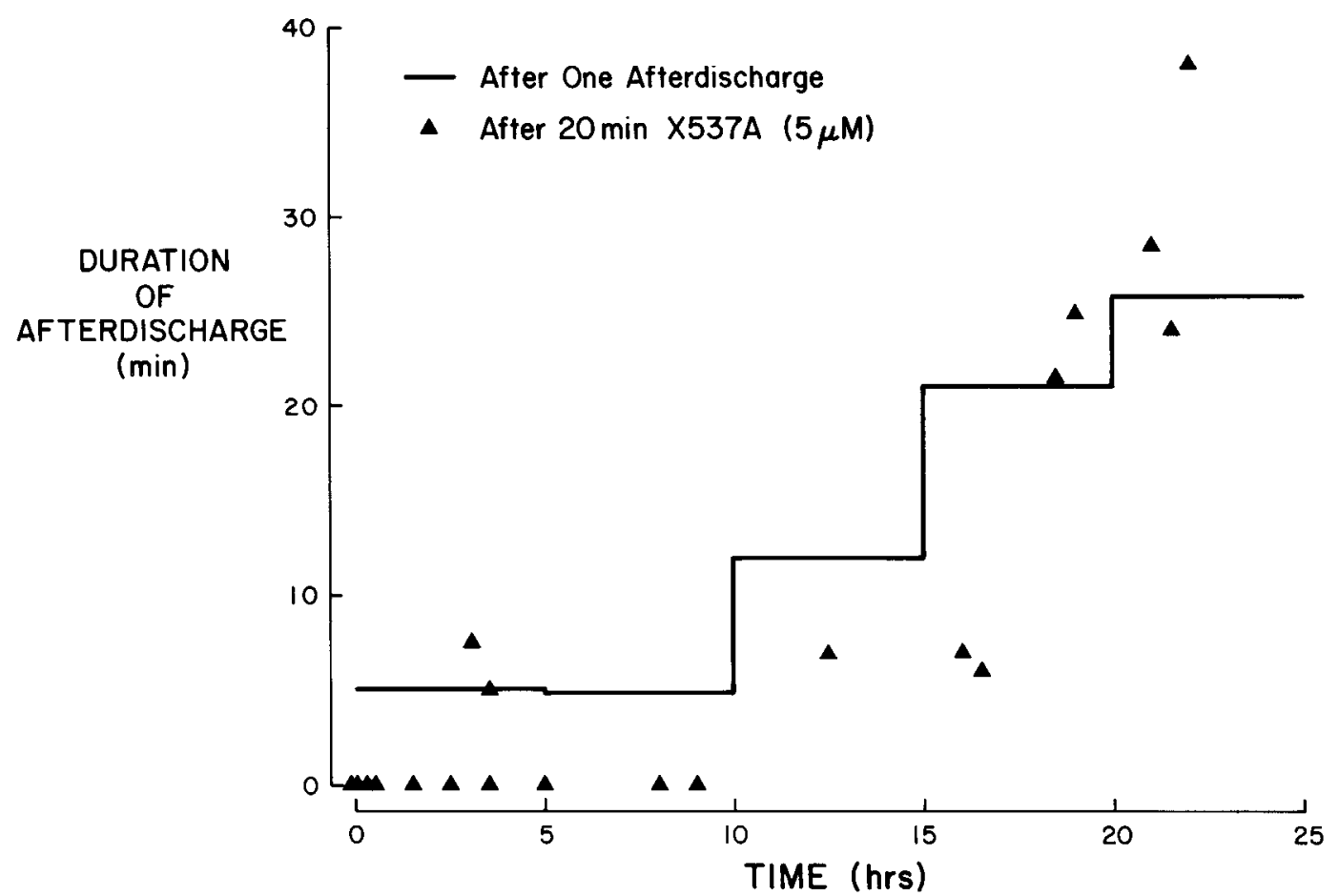

Figure 4. The time course of recovery from X537A exposure is very similar to that for recovery from refractoriness induced by an afterdischarge. Bag cell clusters were stimulated at varying times following exposure to X537A (5 $\mu \mathrm{M}, 20 \mathrm{~min})$, and the duration of afterdischarge $(\boldsymbol{A})$ is plotted as a function of time following exposure. Recovery was complete after about 18 hr (mean duration after $18 \mathrm{hr}=27.3 \mathrm{~min}$ ). The solid line shows the time course of recovery from refractoriness induced by stimulation of an afterdischarge (L. K. Kaczmarek and F. Strumwasser, unpublished data).

$10.4 \mathrm{~mm} \mathrm{KCl}, 55.0 \mathrm{~mm} \mathrm{MgCl}_{2}, 10.0 \mathrm{~mm}$ Tris- $\mathrm{HCl}, \mathrm{pH}$ 7.8) and then rinsed in calcium-free ASW for periods of up to $1 \mathrm{hr}$ in order to remove ionophore. They were then returned to normal ASW and stimulated to afterdischarge. Although this treatment had a characteristic effect on the bag cell neurons, it did not induce refractoriness. In three cases, two or three trains of repetitive pulses (Table I, trials 2 to 4 ) were required to initiate afterdischarges. These were also slower to start than normal discharges. The maximal firing rate $(3$ to $6 \mathrm{~Hz}$ ) in a normal afterdischarge occurs within the first $30 \mathrm{sec}$ (Kaczmarek et al., 1982), whereas in these experiments the maximal firing rate (also 3 to $6 \mathrm{~Hz}$ ) occurred $1 \mathrm{~min}$ or more after stimulation in three of the four ganglia. (The mean delay from stimulation to maximal firing rate was $71 \mathrm{sec}, n=4$.) The mean duration of these afterdischarges (30.25 $\min , n=4)$, however, was the same as that of normal first afterdischarges, indicating that $\mathrm{X} 537 \mathrm{~A}$ does not induce a refractory state in the absence of external calcium ions.

The fact that exposure to X537A in calcium-free ASW did not produce a prolonged effect on afterdischarge duration when the cells were returned to normal, calcium-containing medium also implies that the ionophore is probably removed from cell membranes relatively rapidly following its washout from the extracellular space. It is unlikely, therefore, that the prolonged effects of $\mathrm{X} 537 \mathrm{~A}$ exposure in a calcium-containing medium are due to the persistence of the ionophore in bag cell membranes.

Effects of X537A on afterdischarges in calcium-free and sodium-free media. The ionic dependence of the effects of X537A was further examined by its effects on bag cell afterdischarges stimulated in media deficient in calcium or sodium. Omission of either sodium or calcium from the external medium usually results in failure to afterdischarge, but in both cases afterdischarge may be restored by the presence of the potassium channel blocker TEA in the medium. The characteristics of these afterdischarges have been described in detail elsewhere (Kaczmarek et al., 1982).

In a sodium-containing, calcium-free medium $(420 \mathrm{mM}$ $\mathrm{NaCl}, 9.5 \mathrm{mM} \mathrm{KCl}, 50 \mathrm{mM} \mathrm{MgCl}, 90 \mathrm{mM}$ TEA-Br, $9 \mathrm{mM}$ Tris-HCl, $\mathrm{pH}$ 7.8) brief afterdischarges of high frequency ( 2 to $6 \mathrm{~Hz}$ ) may normally be observed. These afterdischarges resemble the early vigorous phase of a normal afterdischarge and may be evoked many times in a preparation with no evidence of refractoriness. Exposure of

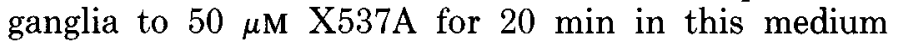
produced no change in the mean duration of afterdischarges, which was the same as that of control ganglia in this medium (Table II).

In a sodium-free, calcium-containing medium $(420 \mathrm{mM}$ Tris- $\mathrm{HCl}, 9.5 \mathrm{mM} \mathrm{KCl}, 10 \mathrm{mM} \mathrm{CaCl} 2,50 \mathrm{mM} \mathrm{MgCl}_{2}, 90$ mM TEA-Br, pH 7.8) stimulation of an afterdischarge does produce a subsequent refractory period (Kaczmarek et al., 1982). In this medium $5 \mu \mathrm{M}$ X537A also suppressed afterdischarge (Table II), although, as in the afterdischarge-induced refractory period, calcium action potentials could still readily be evoked by stimulation of the connective nerve.

The release of peptides by afterdischarge and by X537A. The afterdischarge of the bag cell neurons, which precedes the refractory period, results in the secretion of 
TABLE II

Effect of X537A on duration of afterdischarges in $0-\mathrm{Ca}^{2+}$ and $\mathrm{O}-\mathrm{Na}^{+}$ TEA-containing media

In a calcium-free $\left(0-\mathrm{Ca}^{2+}\right)$ TEA-containing medium $(420 \mathrm{mM} \mathrm{NaCl}$, $9.5 \mathrm{mM} \mathrm{KCl}, 50 \mathrm{mM} \mathrm{MgCl}_{2}, 90 \mathrm{~mm}$ TEA-Br, $9 \mathrm{~mm}$ Tris-HCl, $\mathrm{pH} 7.8$ ) stimulation produced short afterdischarges which could be elicited many times in a preparation. X537A exposure $(50 \mu \mathrm{M}, 20 \mathrm{~min})$ did not affect the mean duration of these discharges. In a sodium-free $\left(0-\mathrm{Na}^{+}\right)$ calcium-containing medium ( $420 \mathrm{~mm}$ Tris- $\mathrm{HCl}, 9.5 \mathrm{~mm} \mathrm{KCl}, 10 \mathrm{~mm}$ $\mathrm{CaCl}_{2}, 50 \mathrm{mM} \mathrm{MgCl} 2,90 \mathrm{~mm}$ TEA-Br, pH 7.8), $5 \mu \mathrm{M}$ X537A did suppress afterdischarge. Durations are given $\pm \mathrm{SEM}$ with the number of afterdischarges in parentheses.

\begin{tabular}{lc}
\hline \multicolumn{1}{c}{ Medium } & Duration of Afterdischarge \\
\hline & seconds \\
$0-\mathrm{Ca}^{2+}$ medium & $42.4 \pm 26.31(19)$ \\
$0-\mathrm{Ca}^{2+}$ medium $+50 \mu \mathrm{M}$ X537A & $53.9 \pm 41.77(17)$ \\
& minutes \\
$0-\mathrm{Na}^{+}$medium & $23.3 \pm 9.9(3)$ \\
$0-\mathrm{Na}^{+}$medium $+5 \mu \mathrm{M} \times 537 \mathrm{~A}$ & $1.37 \pm 1.37(4)$ \\
\hline
\end{tabular}

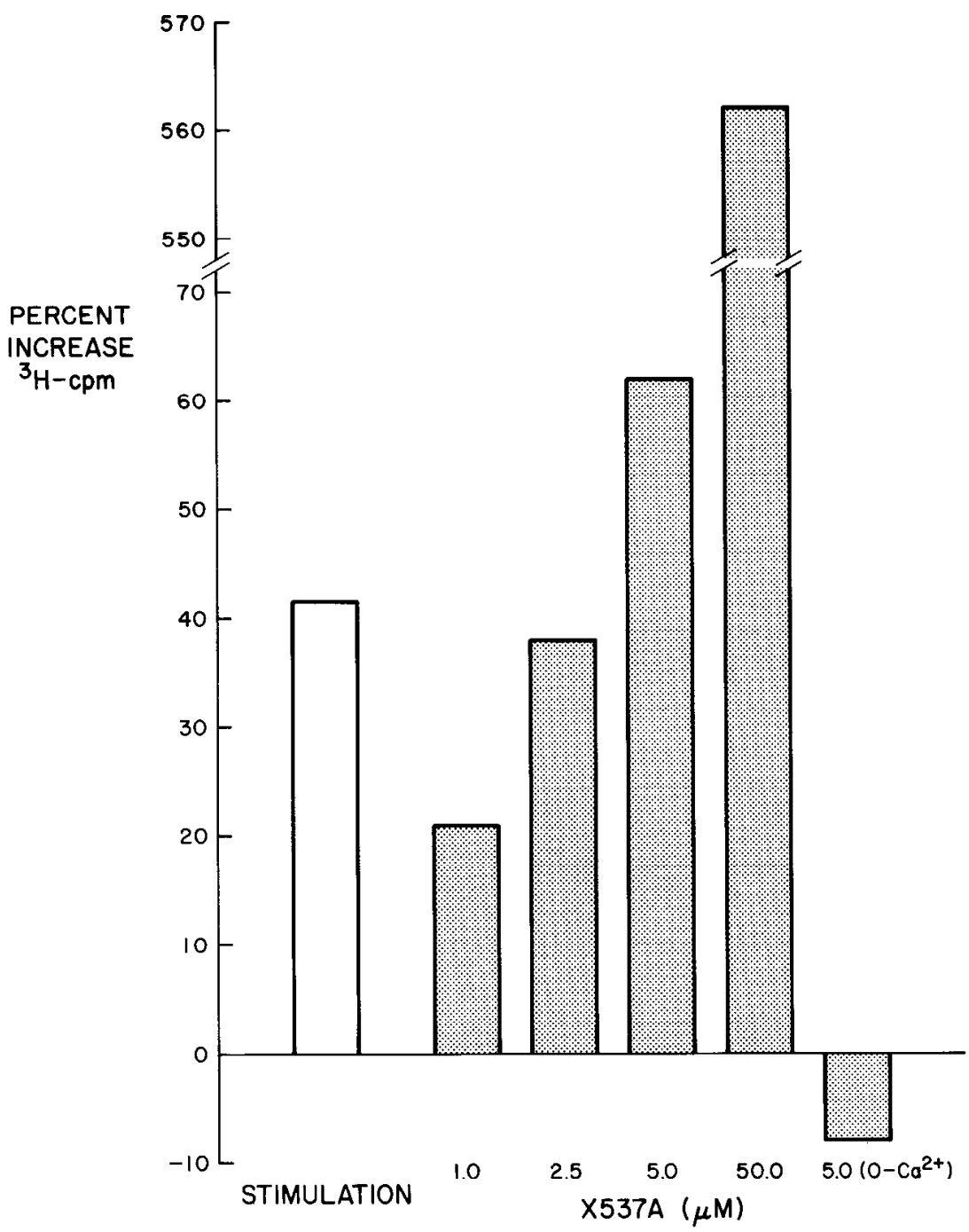

Figure 5. The release of ${ }^{3} \mathrm{H}$-labeled peptides from the bag cell neurons by stimulation and by X537A. Bag cell clusters were labeled for $17 \mathrm{hr}$ at $14^{\circ} \mathrm{C}$ with $25 \mu \mathrm{Ci}$ of $\left[{ }^{3} \mathrm{H}\right]$ leucine, rinsed, and superfused. Samples of released labeled material were collected at 10 -min intervals, precipitated with trichloroacetic acid, washed, and counted. The mean percentage increases over the base line rate of release are shown for the 20 -min period (two consecutive 10 -min collection periods) following electrical stimulation or addition of X537A concentrations from 1.0 to $50.0 \mu \mathrm{M}$ in normal ASW. The histograms for electrical stimulation and for 5.0 $\mu \mathrm{M}$ X537A in normal ASW represent the means of seven and eight experiments, respectively. All other histograms are the means of two individual experiments. The last histogram shows that $5 \mu \mathrm{M}$ X537A in a calcium-free $\left(0-\mathrm{Ca}^{2+}\right)$ superfusing medium of composition $471 \mathrm{mM} \mathrm{NaCl}_{2}, 104 \mathrm{mM} \mathrm{KCl}, 55.0 \mathrm{mM} \mathrm{MgCl}, 10 \mathrm{mM}$ Tris- $\mathrm{HCl}$ (pH 7.8) fails to evoke radiolabeled peptide release. 
charge, whereas $50.0 \mu \mathrm{M}$ X537A produced very much larger increases in ${ }^{3} \mathrm{H}$-peptide efflux. These data correlate well with the dose response data for the induction of refractoriness (Fig. 3); i.e., ionophore concentrations of 2.5 to $5.0 \mu \mathrm{M}$ produce both an increase in peptide release and an attenuation of afterdischarge comparable to those produced by a stimulated afterdischarge. Figure 5 also shows that $5 \mu \mathrm{M}$ X537A failed to induce release in a $\mathrm{Ca}^{2+}$-free extracellular medium.

Effects of X537A on isolated neurons in cell culture. The onset of afterdischarge is associated with increased intracellular cAMP levels and many of the electrical changes that occur in bag cell neurons at the onset of afterdischarge may be observed in isolated bag cell neurons in cell culture following elevation of intracellular cAMP levels (Kaczmarek et al., 1978; Kaczmarek and Strumwasser, 1981a, b). The major effects of cAMP analogues on cultured bag cell neurons include an enhancement of spike height and width, an increase in input resistance, and the emergence of subthreshold oscillations in membrane potential which may generate a repetitive discharge. Further characterization of the electrical effects of 2.5 to $5.0 \mu \mathrm{M}$ X537A was therefore carried out using isolated cultured cells. We found that, although only minor effects were observed on most of the electrical parameters of the cells, their response to repetitive stimulation by a train of current pulses could be dramatically altered by the ionophore.

$\mathrm{X} 537 \mathrm{~A}$, at a concentration that produces a refractory state in intact clusters of cells, was found to have little effect on the action potentials of isolated neurons. Six cells were treated with an activator of adenylate cyclase (100 $\mu \mathrm{M}$ forskolin with $1 \mathrm{mM}$ theophylline (Seamon et al., 1981)), which produces a marked broadening of bag cell action potentials. As is shown in Figure $6 A$, no major changes could be observed in the shape of these enhanced action potentials after $20 \mathrm{~min}$ of exposure to $5 \mu \mathrm{M} \mathrm{X} 537 \mathrm{~A}$, although a very slight narrowing of the spikes could be observed in three of the cells. Two other cells were also treated with this concentration of ionophore without prior treatment with the adenylate cyclase activator. Again, no significant changes in action potential shape were observed after $20 \mathrm{~min}$, and subsequent treatment with the adenylate cyclase activator was able to enhance the action potentials. Incubation of the isolated cultured bag cell neurons with $5 \mu \mathrm{M}$ X537A for periods longer than $20 \mathrm{~min}$, however, could produce attenuation of the spikes.

Figure $7 B$ shows that $\mathrm{X} 537 \mathrm{~A}$ had little effect on forskolin-induced oscillations in membrane potential. In only one of six cells was significant attenuation of the subthreshold oscillations observed after addition of $5 \mu \mathbf{M}$ $\mathrm{X} 537 \mathrm{~A}$. In two cells input resistance was monitored by measuring the voltage response to a series of hyperpolarizing current pulses. As described earlier for cAMP analogues (Kaczmarek and Strumwasser, 1981a) and for injections of the catalytic subunit of cAMP-dependent protein kinase (Kaczmarek et al., 1980), the adenylate cyclase activator produced increases in input resistance. This increased input resistance was not affected by subsequent exposure to $5 \mu \mathrm{M}$ X537A for $20 \mathrm{~min}$ (Fig. $7 \mathrm{~A}$ ).

A major change in the response to repetitive intracellular stimulation was, however, observed in certain cells following addition of X537A. A large cumulative depolarization during stimulation at a frequency close to 1 $\mathrm{Hz}$ was seen in three of six cells. In two of these cells the response was observed only after elevation of cAMP levels by forskolin (Fig. 6B), whereas in the third cell the cumulative depolarization was already evident without forskolin treatment. This response resembles the cumulative depolarization seen at the onset of afterdischarge in intact clusters of cells (Fig. 1) and may result in multiple spikes being triggered by later current pulses in the train (e.g., pulse 5 in Fig. $6 B$, center). The depolarization generally decayed over a period of several seconds after the end of the stimulus train. In each case,
A CONTROL
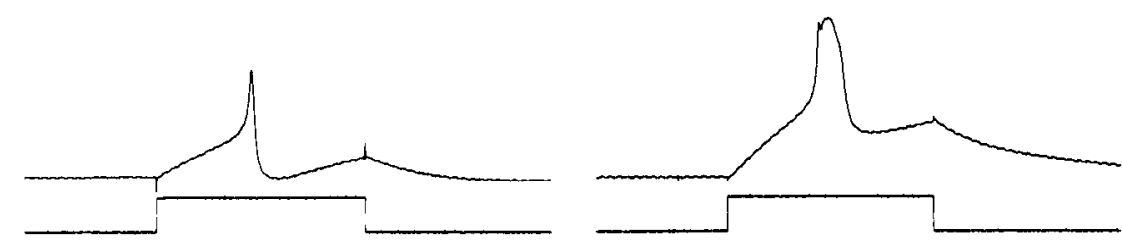

B
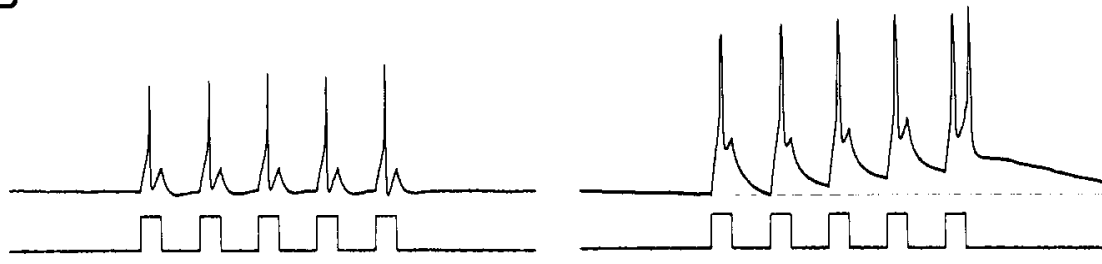

CAMP $++\times 537 A$
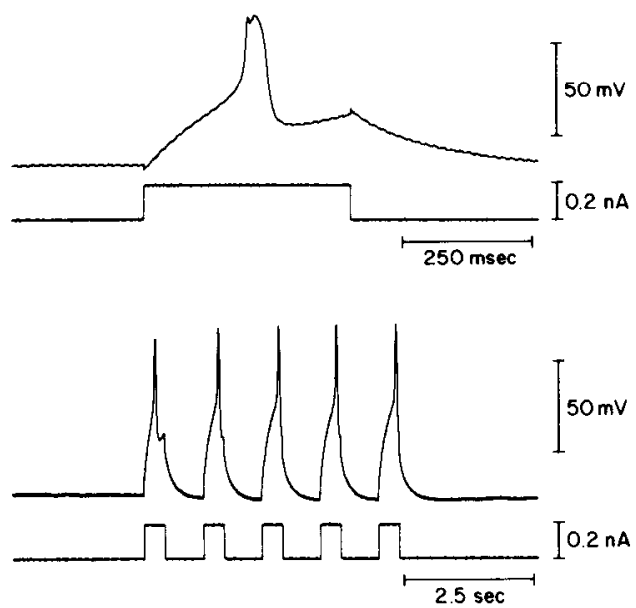

Figure 6. X537A does not significantly alter the action potentials of isolated bag cell neurons but abolishes the cumulative depolarization that follows repetitive stimulation in cells with elevated cAMP levels. $A$, Intracellular recordings from an isolated bag cell neuron before (left ) and after (center) addition of the adenylate cyclase activator forskolin (100 $\mu \mathrm{M})$ and theophylline (1 $\mathrm{mM})$. The action potentials become markedly enhanced by this treatment. The right panel shows that X537A (5 $\mu \mathrm{M}, 20 \mathrm{~min})$ does not significantly affect spike electrogenesis. $B$, Intracellularly recorded responses to multiple stimuli in the same cell as $A$, before and after forskolin + theophylline (left and center) and after subsequent exposure to X537A. The ionophore selectively eliminates the cumulative depolarization that follows repetitive stimulation. 
A

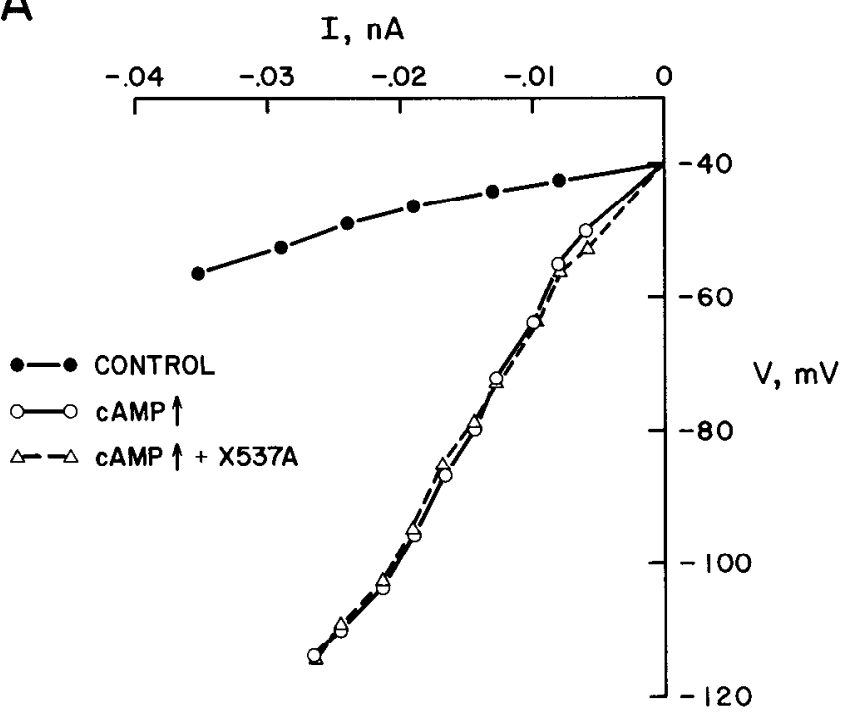

B

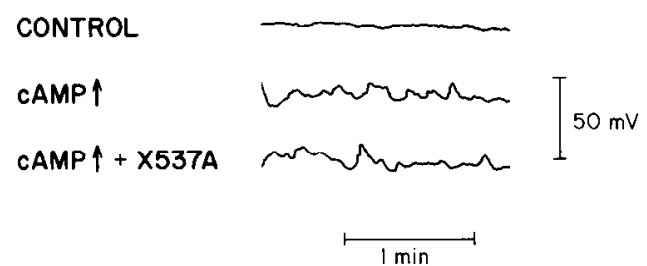

Figure 7. Absence of an effect of X537A on input resistance and subthreshold oscillations in membrane potential of cultured bag cell neurons. $A$, Input resistance was measured by the response of the membrane potential to a series of hyperpolarizing current pulses. Elevation of intracellular cAMP levels $(c A M P \uparrow)$ with $100 \mu \mathrm{M}$ forskolin and $1 \mathrm{mM}$ theophylline produced a very marked increase in input resistance in this cell. Subsequent addition of $5 \mu \mathrm{M}$ X537A for $20 \mathrm{~min}$ ( $c A M P \uparrow$ $+X 537 A$ ) did not alter input resistance. $B$, Oscillations in the membrane potential of a cultured bag cell neuron were induced by forskolin and theophylline $(c A M P \uparrow)$. Subsequent addition of $2.5 \mu \mathrm{M}$ X537A for $20 \mathrm{~min}(c A M P \uparrow+X 537 A)$ did not significantly alter the oscillations.

the response could be elicited many times without apparent attenuation. In all three cells, however, the cumulative depolarization was abolished after $20 \mathrm{~min}$ exposure to $5 \mu \mathrm{M}$ X537A such that stimulation resulted only in a small hyperpolarization at the end of the train of pulses (Fig. $6 B$ ).

\section{Discussion}

The failure to respond more than once to a stimulus which produces an afterdischarge is the normal behavior of a number of cells of both invertebrates and vertebrates (Dufy et al., 1979; DeVlieger et al., 1980) and finds pathological expression in the post-ictal depression of vertebrate neurons following epileptic seizures (Jasper et al., 1969). In the bag cell neurons, the prolonged refractory period that follows an afterdischarge probably has an important biological function. A bag cell afterdischarge results in the secretion of neuroactive peptides which trigger a temporal sequence of changes in the activity of other neurons (Mayeri and Rothman, 1981) and leads to a series of fixed acts comprising egg-laying behavior, which may last for several hours. Therefore, it is likely that a second afterdischarge, during the later stages of egg-laying, would disrupt the coordination of this behavior. A prolonged refractory period prevents such an occurrence.

We have shown that brief exposure to the divalent cationophore X537A in a calcium-containing medium is capable of producing a refractory period in the bag cell neurons. In its effects on afterdischarge duration, its dependence on external calcium ions, its prolonged time course, and its response to extracellular TEA ions, this ionophore-induced refractory period appears very similar to the refractory period that normally follows a bag cell afterdischarge. Our data show that ionophore concentrations of 2.5 to $5 \mu \mathrm{M}$ quantitatively mimic an afterdischarge, both in the increase in peptide release that they evoke and in the degree to which they suppress subsequent afterdischarges. As the ionophore generates no detectable spontaneous electrical activity within the bag cell neurons and produces no significant change in resting potentials, the results support the idea that calcium entry during an afterdischarge is sufficient to cause the subsequent refractory period.

We do not know, as yet, by how much or for how long intracellular calcium ion concentrations are elevated during and after a bag cell afterdischarge or exposure to ionophore. The fact that similar increases in total ${ }^{3} \mathrm{H}$ labeled peptide release were obtained with stimulated afterdischarge and with ionophore concentrations that produce refractoriness suggests that, at least at intracellular release sites, the effective internal calcium concentration may be similar for these two treatments. Direct measurements of intracellular calcium ion concentrations will, however, be needed to establish this.

At concentrations that produce refractoriness, the ionophore blocked the ability of repetitive intracellular stimulation to produce a cumulative depolarization in isolated cultured bag cell neurons. Most of the other properties of these cells, including spike genesis and the ability to respond to elevated cAMP levels with spike broadening, increased input resistance, and subthreshold oscillations in membrane potential, appeared to be relatively unaffected. We do not yet know the ionic basis of the cumulative depolarization. Nor can we be sure that this is the only change in the electrical properties of the bag cell system during the refractory period since, in intact bag cell clusters, afterdischarge normally originates in the distal tips of bag cell neurites, at a distance of 5.0 to $10.0 \mathrm{~mm}$ from the somata (Dudek and Blankenship, 1977a, b; Kaczmarek et al., 1978). Nevertheless it is very likely that this loss of the ability to depolarize with repetitive stimulation, which also occurs in response to connective nerve stimulation in intact clusters of cells, is the major cause of the cells' failure to afterdischarge.

One of the most intriguing aspects of the refractory period of the bag cell neurons is its prolonged time course. A simple hypothesis for the long-lasting nature of the change in electrical properties is that calcium entry causes a long-lasting inactivation of a membrane conductance, possibly through calcium-dependent proteo- 
lysis or phosphorylation (DeReimer et al., 1982; NovakHofer and Levitan, 1983). Other possibilities are that secretion during an afterdischarge causes the depletion of a bag cell peptide which normally excites an autoreceptor on the bag cell neurons, or that calcium causes changes in the number of specific membrane channels through membrane exocytosis or reuptake. Any of these very different types of mechanism could produce a cellular change consistent with the prolonged time course of the refractory period.

\section{References}

Acosta-Urquidi, J., and F. E. Dudek (1981) Soma spike of neuroendocrine bag cells of Aplysia californica. J. Neurobiol. 12: $367-378$.

Arch, S. (1972) Polypeptide secretion from the isolated parietovisceral ganglion of Aplysia californica. J. Gen. Physiol. 59. $47-59$.

DeRiemer, S. A., L. K. Kaczmarek, and P. Greengard (1982) Calcium/calmodulin-dependent protein phosphorylation in Aplysia neurons. Soc. Neurosci. Abstr. 8: 565 .

DeVlieger, T. A., K. S. Kits, A. Ter Maat, and J. C. Lodder (1980) Morphology and electrophysiology of the ovulation hormone producing neuroendocrine cells of the freshwater snail Lymnea slagnalis. J. Exp. Biol. 84: 259-271.

Dudek, F. E, and J. E. Blankenship (1977a) Neuroendocrine cells of Aplysia brasiliana. I. Bag cell action potentials and afterdischarge. J. Neurophysiol. 40: 1301-1311.

Dudek, F. E., and J. E. Blankenship (1977b) Neuroendocrine cells of Aplysia brasiliana. II. Bag cell prepotentials and potentiation. J. Neurophysiol. 40: 1312-1324.

Dudek, F. E., J. S. Cobbs, and H. M. Pinsker (1979) Bag cell electrical activity underlying spontaneous egg laying in freely behaving Aplysia brasiliana. J. Neurophysiol. 42: 804-817.

Dufy, B., J. D. Vincent, H. Fleury, P., DuPasquier, D. Gourdji, and A. Tixier-Vidal (1979) Membrane effects of thyrotropinreleasing hormone and estrogen shown by intracellular recording from pituitary cells. Science 204: 509-511.

Eckert, R., and D. Ewald (1982) Residual calcium ions depress activation of calcium-dependent current. Science 216: 730 733.

Jasper. H. H., A. A. Ward, and A. Pope (1969) Basic Mechanisms of the Epilepsies, Little, Brown \& Co., Boston.

Kaczmarek, L. K., and F. Strumwasser (1981a) The expression of long-lasting afterdischarge by isolated Aplysia bag cell neurons. J. Neurosci. 1: 626-634.

Kaczmarek, L. K., and F. Strumwasser (1981b) Net outward currents of bag cell neurons are diminished by a cAMP analogue. Soc. Neurosci. Abstr. 7: 932.

Kaczmarek, L. K., K. Jennings, and F. Strumwasser (1978) Neurotransmitter modulation, phosphodiesterase inhibitor effects, and cAMP correlates of afterdischarge in peptidergic neurites. Proc. Natl. Acad. Sci. U. S. A. 75: 5200-5204.

Kaczmarek, L. K., M. Finbow, J. P. Revel, and F. Strumwasser (1979) The morphology and coupling of Aplysia bag cells within the abdominal ganglion and in cell culture. J. Neurobiol. 10: 535-550.

Kaczmarek, L. K., K. R. Jennings, F. Strumwasser, A. C. Nairn, U. Walter, F. D. Wilson, and P. Greengard (1980) Microinjection of catalytic subunit of cyclic AMP-dependent protein kinase enhances calcium action potentials of bag cell neurons in cell culture. Proc. Natl. Acad. Sci. U. S. A. 77: 7427-7491.

Kaczmarek, L. K., K. R. Jennings, and F. Strumwasser (1982) An early sodium and a late calcium phase in the afterdischarge of peptide secreting neurons of Aplysia. Brain Res. 238: $105-115$.

Kupfermann, I., and E. R. Kandel (1970) Electrophysiological properties and functional interconnections of two symmetrical neurosecretory clusters (bay cells) in abdominal ganglion of Aplysia. J. Neurophysiol. 33: 865-876.

Mayeri, E., and B. S. Rothman (1981) Nonsynaptic peptidergic neurotransmission in the abdominal ganglion of Aplysia. In D. S. Farner and K. Lederis, eds., Neurosecretion-Molecules, Cells, Systems, pp. 305-316, Plenum Press, New York.

Meech, R. W. (1978) Calcium-dependent potassium activation in nervous tissues. Annu. Rev. Biophys. Bioeng. 7: 1-18.

Novak-Hofer, I., and I. B. Levitan (1983) $\mathrm{Ca}^{++} /$calmodulinregulated protein phosphorylation in the Aplysia nervous system. J. Neurosci. 3: 473-481.

Pinsker, H. M., and F. E. Dudek (1977) Bag cell control of egg laying in freely-behaving Aplysia. Science 197: 490-493.

Pressman, B. C. (1972) Carboxylic ionophores as mobile carriers for divalent ions. In The Role of Membranes in Metabolic Regulation, M. A. Mchlman and R. W. Hanson, eds., pp. 149-164, Academic Press, Inc., New York.

Seamon, K. B., W. Padgett, and J. W. Daly (1981) Forskolin: Unique diterpene activator of adenylate cyclase in membranes and in intact cells. Proc. Natl. Acad. Sci. U. S. A. 78: 3363-3367.

Stuart, D. K., A. Y. Chiu, and F. Strumwasser (1980) Neurosecretion of egg-laying hormone and other peptides from electrically active bag cell neurons of Aplysia. J. Neurophysiol. 43: 488-498.

Tillotson, D., and R. Horn (1978) Inactivation without facilitation of calcium conductance in caesium-loaded neurons of Aplysia. Nature 273: 312-314. 